\title{
Identification of an endoflagellar associated protein in Borrelia burgdorferi
}

\author{
H. EIFFERT*, T. SCHLOTT, M. HOPPERTt, HANNELORE LOTTER and R. THOMSSEN \\ Department of Medical Microbiology and †Institute of Microbiology, University of Göttingen, Germany
}

\begin{abstract}
Summary. DNA of Borrelia burgdorferi was cleaved by the endonuclease EcoRI and ligated with the bacteriophage expression vector $\lambda$ gt 11 . After infection of the Escherichia coli strain Y1089, the plaques of recombinant phages were screened with a $B$. burgdorferi antiserum (human) for fusion proteins containing borrelia antigens. A positive clone produced a hybrid protein (p200) of $c .200 \mathrm{Kda}$. The corresponding native borrelia protein (p97) was identified as having an $\mathrm{M}_{\mathrm{r}}$ of $97 \mathrm{Kda}$. To localise protein $\mathrm{p} 97$ in the $B$. burgdorferi cell, immunoelectronmicroscopy and a Western blot of isolated flagella were used. Antibodies directed against proteins p200 and p97 recognised epitopes associated with the flagella.
\end{abstract}

\section{Introduction}

Borrelia burgdorferi is the causative agent of Lyme disease, a multisystem disorder characterised by various clinical manifestations at different stages. ${ }^{1}$ The bacterium represents a new species of Borrelia and is related to other spirochaetal pathogens such as Treponema and Leptospira. ${ }^{2,3}$ Little is known about the protective role of antibodies or about pathogenesis. Some of the major antigens of $B$. burgdorferi have been investigated by gel electrophoresis and immunological methods, and partly by cloning and nucleotide sequencing. The best characterised molecules are the outer-surface proteins OspA, OspB and $\mathrm{pC}^{4-8}$ the major flagellar protein $\mathrm{p} 41^{9-11}$ and the "common antigen" with an $\mathrm{M}_{\mathrm{r}}$ of $c .60 \mathrm{Kda} .{ }^{12}$ The common antigen and p41 share epitopes with other bacteria. ${ }^{5,9,12}$ In this report a further protein of $B$. burgdorferi is described.

\section{Materials and methods}

\section{Bacterial strains}

$B$. burgdorferi strain IRS Us was isolated, as described by others, ${ }^{13}$ from a tick (Ixodes ricinus) found near Göttingen. E. coli strains JM 109, Y1089 and Y1090 were provided by Stratagene Ltd, Heidelberg, Germany.

\section{Cultivation of $B$. burgdorferi and antigen preparation}

Large scale cultivation was by the method of Barbour. ${ }^{14}$ The strain was grown in a modified BSK

Received 26 March 1991; accepted 31 May 1991.

* Correspondence should be sent to Dr H. Eiffert, Hygiene Institut, Kreuzbergring 57, D-3400 Göttingen, Germany. medium for 5 days at $33^{\circ} \mathrm{C}$. The spirochaetes were harvested by centrifugation at $10000 \mathrm{~g}$ for $30 \mathrm{~min}$ at $4^{\circ} \mathrm{C}$. The pellet was washed three times in phosphatebuffered saline (PBS) pH 7.4 and resuspended. The suspension was disintegrated in an ice bath by means of three 5-s bursts from a sonifier (Branson Sonic Power Co., Danburry, USA) operating at $30 \%$ maximal intensity. The preparation was then centrifuged at $10000 \mathrm{~g}$ for $30 \mathrm{~min}$ at $4^{\circ} \mathrm{C}$. The supernate containing borrelia antigen was stored in small volumes at $-24^{\circ} \mathrm{C}$.

\section{Serum samples}

These were obtained from the $B$. burgdorferi diagnostic laboratory, Department of Medical Microbiology, University of Göttingen, Germany. The serum used for screening for the fusion proteins was obtained from a forestry worker with clinical symptoms of Lyme disease and a high concentration of $\boldsymbol{B}$. burgdorferi antibodies. The antibodies were detected by an IgM capture ELISA and an IgG ELISA. ${ }^{15}$

\section{Preparation of B. burgdorferi DNA}

A culture $(500 \mathrm{ml})$ was prepared by a modification ${ }^{4}$ of a method described previously. ${ }^{16}$ After centrifugation, the cells were suspended in $1 \mathrm{ml}$ of $50 \mathrm{mM}$ Tris $\mathrm{HCl}, \mathrm{pH} 7.6$, containing sucrose $25 \% \mathrm{w} / \mathrm{w}$ and lysozyme (Boehringer, Mannheim, Germany) $2 \mathrm{mg}$ and incubated for $30 \mathrm{~min}$ at $37^{\circ} \mathrm{C}$. Thereafter, $0.4 \mathrm{ml}$ of $0.25 \mathrm{M}$ edetic acid, $\mathrm{pH} 8.0$, and $0.16 \mathrm{ml}$ of sodium dodecylsulphate (SDS) $10 \% \mathrm{w} / \mathrm{w}$ were added and mixed. This lysate was digested with $0.5 \mathrm{mg}$ of proteinase $\mathrm{K}$ (Boehringer) for $60 \mathrm{~min}$ at $37^{\circ} \mathrm{C}$ and extracted with phenol-chloroform; the DNA was then precipitated with ethanol. ${ }^{17}$ 


\section{Preparation and screening of the expression library}

The isolated DNA of $B$. burgdorferi was digested completely by the restriction enzyme EcoRI (Pharmacia, Uppsala, Sweden). For removal of RNA, DNAase-free RNAase $0.1 \mathrm{mg} / \mathrm{ml}$ was added and incubated at $37^{\circ} \mathrm{C}$ for $60 \mathrm{~min}$. The process of cleavage was monitored by agarose gel electrophoresis. After extraction with phenol-chloroform and precipitation with ethanol, the DNA was dried in a vacuum.

The DNA was ligated into EcoRI-digested, dephosphorylated $\lambda$-gt11 DNA (Bethesda Research Laboratories, Gaithersburg, USA) and packaged with DNA Packaging Kit (Boehringer) as described by the manufacturers. A suspension $(100 \mu \mathrm{l})$ of the competent $E$. coli strain Y1089 was transfected with $1 \mu$ l of the suspension of recombinant bacteriophages for $60 \mathrm{~min}$ at $37^{\circ} \mathrm{C}$ and then added to $3 \mathrm{ml}$ of soft agar containing $10 \mathrm{mM} \mathrm{MgSO}_{4}$, ampicillin $0.01 \%$ and $0.3 \mathrm{mM}$ isopropyl- $\beta$-D-thiogalactoside (IPTG). The soft agar was then poured on to Luria broth (LB) plates ${ }^{17}$ containing ampicillin $0.01 \%$ and incubated overnight at $37^{\circ} \mathrm{C}$. Replicas of the plates were obtained by carefully placing dry nitrocellulose filter disks (Schleicher and Schüll, Dassel, Germany) on the soft agar for $30 \mathrm{~min}$ at $37^{\circ} \mathrm{C}$. These were then removed and the position was marked on the plate with a needle. The filters were rinsed with $\mathrm{PBS}^{17}$ and incubated with milk powder (Uelzena, Uelzen, Germany) $5 \% \mathrm{w} / \mathrm{w}$ in $5 \mathrm{ml}$ of PBS for $30 \mathrm{~min}$ at room temperature. Human sera with $B$. burgdorferi antibodies, or negative human sera, were then added in a final dilution of 1 in 1000 and incubated for $60 \mathrm{~min}$ at room temperature. After four 5 -min washes with Tween $0.05 \% \mathrm{w} / \mathrm{w}$ in PBS, positive clones were detected by standard methods with peroxidase-labelled rabbit antibodies against human serum (Dako, Copenhagen, Denmark).

Positive clones were identified by the colour reaction and recognised on the LB plate. The phages were isolated and stored at $4^{\circ} \mathrm{C}$ in $0.5 \mathrm{ml}$ of SM buffer ${ }^{17}$ containing $5 \mu \mathrm{l}$ of chloroform. Five of about 20000 plaques showed a positive reaction.

\section{Expression of the fusion protein in E. coli strain Y1090}

To increase the amount of the hybrid protein, $E$. coli strain Y1090 was infected with the recombinant bacteriophage $\lambda$ by the method of Huynh et al ${ }^{18}$ The lysogenic E. coli strain Y1090 was incubated in $3 \mathrm{ml}$ of $\mathrm{LB}$ medium containing $10 \mu \mathrm{l}$ of $1 \mathrm{M} \mathrm{MgSO}_{4}$ and $3 \mu \mathrm{l}$ of ampicillin $10 \%$ overnight at $32^{\circ} \mathrm{C}$. LB medium $(2 \mathrm{ml})$ was then added and incubated at $45^{\circ} \mathrm{C}$ for $20 \mathrm{~min}$. IPTG was added to a final concentration of $10 \mathrm{~mm}$. This mixture was incubated at $37^{\circ} \mathrm{C}$ for $2 \mathrm{~h}$ and centrifuged at $1500 \mathrm{~g}$ for $15 \mathrm{~min}$. The resulting pellet was resuspended in $50 \mu \mathrm{l}$ of PBS and stored at $-20^{\circ} \mathrm{C}$. After being thawed, the cells were lysed and the proteins were investigated.

\section{Electrophoresis and immunoblotting}

The proteins were separated by a standard SDSpolyacrylamide gel electrophoresis (PAGE). ${ }^{19}$ The gels were stained with Coomassie Blue. Electroblotting was performed with a polyvinylidenedifluoride membrane (PVDF, Millipore, Bedford, USA) as described by Gültekin and Heermann. ${ }^{20}$ For the detection of bound antibodies, peroxidase labelled anti-human or anti-rabbit antibodies (Dako) were used.

\section{Elution of specific antibodies}

For the elution of specific antibodies from blot membranes, the technique described by Olmsted ${ }^{21}$ was used.

\section{Electro-elution}

Fusion protein was electro-eluted from a preparative SDS-polyacrylamide gel into a membrane trap (Biotrap, Schleicher und Schüll). ${ }^{22}$

\section{Absorption procedure}

E. coli lysate $(100 \mu \mathrm{g})$, before or after infection with the recombinant bacteriophage, or electro-eluted protein p200 $(30 \mu \mathrm{g})$ was mixed with $100 \mu \mathrm{l}$ of serum containing $B$. burgdorferi antibodies. Absorbed and untreated control samples were held at room temperature for $4 \mathrm{~h}$.

\section{Immunisation of the rabbits}

Rabbits were immunised subcutaneously with $0.8 \mathrm{mg}$ of electro-eluted protein p200 after dialysis against $\mathrm{NaCl} 0.9 \% \mathrm{w} / \mathrm{v}$. To $1 \mathrm{ml}$ of the solution, $1 \mathrm{ml}$ of Freund's complete adjuvant was added. The immunisation procedure was repeated three times at intervals of 2 weeks. The negative control serum was obtained before immunisation. The specific antiserum used for immuno-electronmicroscopy was purified by affinity chromatography on protein A-Sepharose CL4B (Pharmacia, Uppsala, Sweden).

\section{Isolation of endoflagella}

Flagella were obtained from B.burgdorferi by ultracentrifugation. $^{9}$

\section{Immuno-electronmicroscopy}

$B$. burgdorferi cells from a $100-\mathrm{ml}$ culture were harvested by centrifugation at $13000 \mathrm{~g}$ for $10 \mathrm{~min}$ and fixed in a solution of formaldehyde $0.2 \% \mathrm{w} / \mathrm{v}$ and glutaraldehyde $0.3 \% \mathrm{v} / \mathrm{v}$ in PBS for $1 \mathrm{~h}$ at $0^{\circ} \mathrm{C}$. The samples were embedded in the low temperature resin Lowicryl K4M (Chem. Werke Lowi, Waldkraiburg, Germany). ${ }^{23}$ Post-embedding labelling for the immuno-electronmicroscopic localisation of p97 was performed on ultrathin sections with the protein Acolloidal gold technique. ${ }^{24-26}$ To reduce non-specific 
binding, casein $1 \% \mathrm{w} / \mathrm{v}$ was added to the solutions containing immunoglobulins or protein A-gold. Poststaining of the sections was with uranyl acetate $(\mathrm{pH}$ $4.8) 4 \%$ for $3 \mathrm{~min}$.

For immuno-electronmicroscopy of the isolated flagella, a grid covered with a carbon-coated Formvar film was floated on a drop of the sample. The grid was removed, dried and then incubated in serum from the immunised rabbit for $1 \mathrm{~h}$. After incubation, the grid was floated on two drops of PBS containing Tween $0.05 \%$ and one drop of PBS for 2 min to remove nonspecific antibodies. The grid was then floated on a drop containing a 1 in 50 dilution of $5-\mathrm{nm}$ colloidal gold particles coated with protein $\mathrm{A}^{24}$ for $1 \mathrm{~h}$. The grid was washed in two drops of PBS containing Tween $0.05 \%$ and one drop of distilled water and was finally stained by floating on a drop of phosphotungstic acid (pH 7.0) $2 \%$. Electronmicrographs were taken with a Philips EM 301 instrument (Philips, Eindhoven, Netherlands) at calibrated magnifications.

\section{Isolation and characterisation of the DNA of the recombinant $\lambda \mathrm{gt} 11$}

The cultivation of the recombinant $\lambda \mathrm{gt} 11$ and the isolation of the bacteriophage DNA was carried out by the plate lysate method..$^{17}$ The purified DNA was cleaved with $E c o$ RI and the restriction fragments were analysed by agarose gel electrophoresis after staining with ethidium bromide.

\section{Results}

For the cloning of immunogenic protein sequences, DNA of B. burgdorferi was isolated and cleaved with the endonuclease EcoRI, and the DNA fragments were ligated with the $E c o$ RI site of the bacteriophage $\lambda$ gt11. For the screening of the resulting gene bank, the fusion proteins were expressed in $E$. coli strain Y1089. The hybrid proteins, expressed by the recombinant phages, consisted of $\beta$-galactosidase and random sequences of $B$. burgdorferi. These were recognised in colony immuno-screening if they represented an antigenic structure of $B$. burgdorferi. Five of c. 20000 plaques showed a positive reaction and no reaction with the negative controls. One of these five clones was investigated further and described for this study. To obtain larger amounts of the fusion protein, the phages were subcloned in E. coli strain Y1090. The cell lysate of this clone was analysed by SDS-PAGE. An additional band of $c .200 \mathrm{Kda}(\mathrm{p} 200)$ was identified after staining the $E$. coli lysate with Coomassie Blue, in comparison with an $E$. coli lysate after infection with $\lambda$ gt11 without a $B$. burgdorferi insert. This band was also recognised by the human serum containing B. burgdorferi antibodies (fig. 1) but not with a negative human serum. Other bands of the lysate showed only weak reactions.

To characterise the polypeptide of $B$. burgdorferi

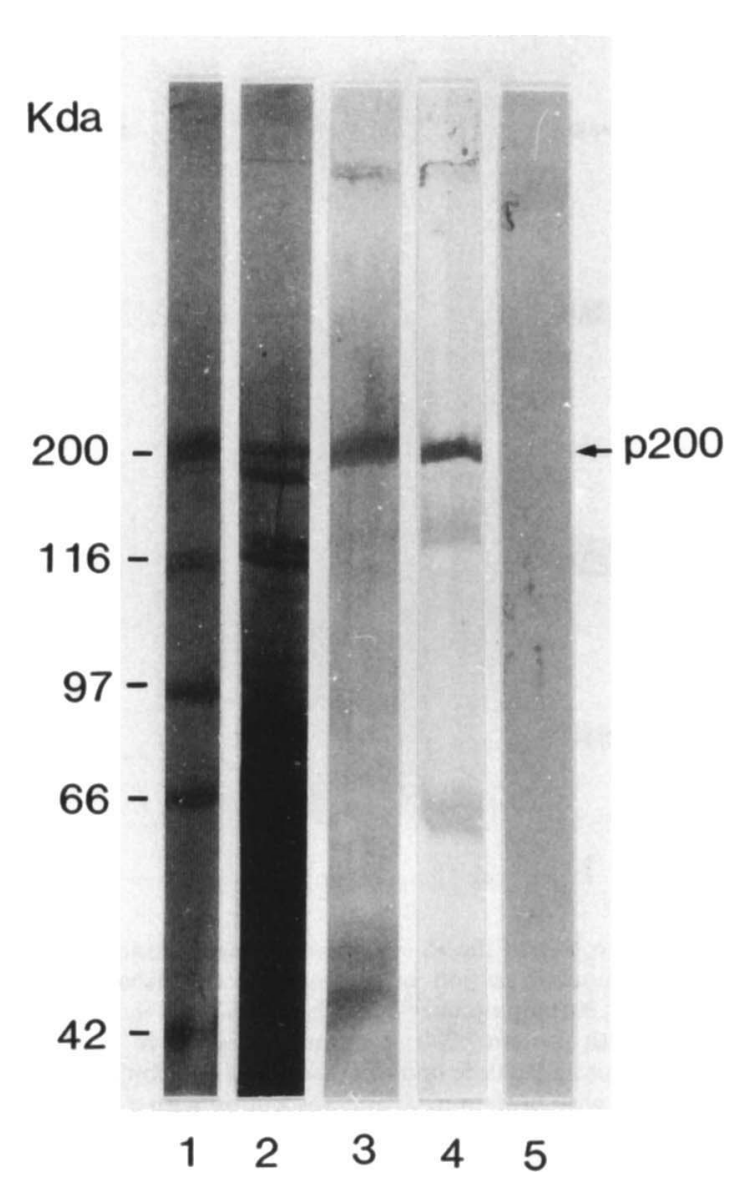

Fig.1. Western blot of the transfected $E$. coli strain Y1089 lysate: lane 1, mol. wt marker; 2, staining with Coomassie Blue; 3 , immunoreaction with $B$. burgdorferi antibody-positive human serum; 4, immunoreaction with $\beta$-galactosidase antibodies; 5 , immunoreaction with $B$. burgdorferi antibody-negative human serum.

present in the fusion protein, three methods were used. Firstly, the 200-Kda protein was electro-eluted from a preparative SDS-PAGE gel and added to the $B$. burgdorferi antiserum for absorption of the antibodies that recognised the $200-\mathrm{Kda}$ protein. $B$. burgdorferi antigen was separated by SDS-PAGE and transferred to the PVDF membrane. The positive serum, with or without absorption by the fusion protein, was incubated with the blot. In the blot, immunostained by the pre-absorbed serum, a band of $c .97 \mathrm{Kda}$ was missing, compared with the result given by the non-absorbed serum (fig. 2, lane 3). Secondly, antibodies were eluted from protein $\mathrm{p} 200$ bound to the blot membrane. This eluate reacted with the $97-\mathrm{Kda}(\mathrm{p} 97)$ protein of $B$. burgdorferi in Western blots (fig. 2, lane 4). Thirdly, a rabbit was immunised with the gel-purified fusion protein. The resulting antibodies reacted in Western blots with protein p200 in the $E$. coli lysate, and from the blotted $B$. burgdorferi, antigen $\mathrm{p} 97$ was recognised (fig. 2 , lane 5). Anti- $\beta$-galactosidase antibodies stained only p 200.

Out of 20 sera with B. burgdorferi antibodies of the IgG and IgM class, four showed strong reactions, 13 


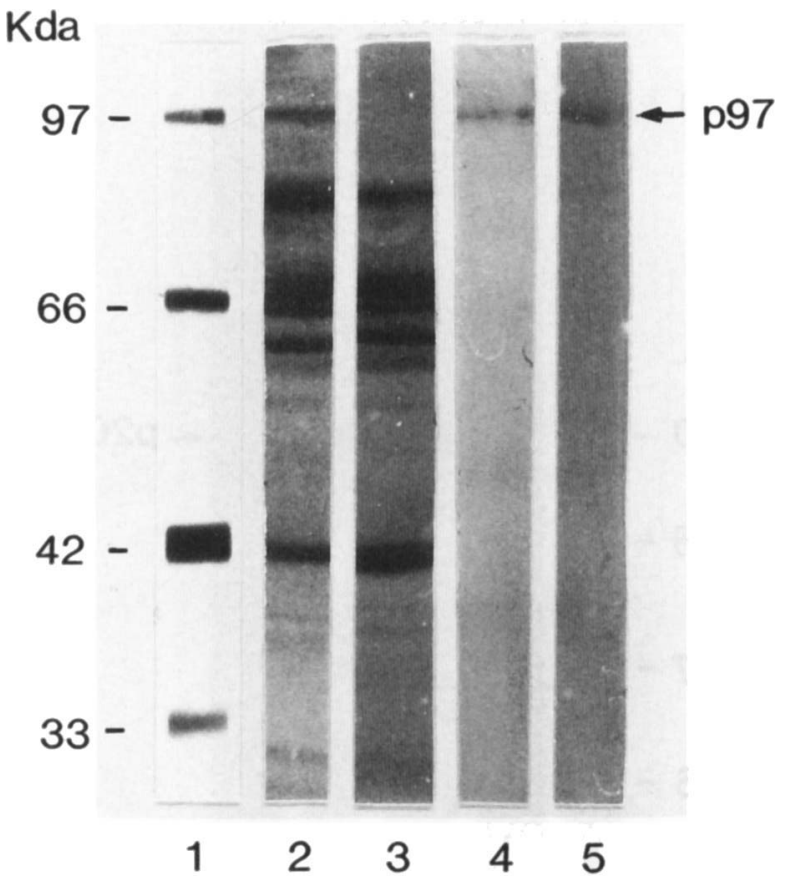

Fig. 2. Western blot of the $B$. burgdorferi antigen: lane 1, mol. wt marker; 2, immunoreaction of $\boldsymbol{B}$. burgdorferi antibody-positive human serum; 3 , immunoreaction of the serum used in lane 2 after absorption with protein p200; 4, immunoreaction of antibodies, eluted from protein $\mathrm{p} 200 ; \mathbf{5}$, immunoreaction of a rabbit serum after immunisation with protein $\mathrm{p} 200$ and absorption with a negative $E$. coli lysate.

weak reactions and three no reaction with $\mathrm{p} 97$ in a Western blot. The 20 negative controls did not react.

The localisation of protein $\mathrm{p} 97$ in the $B$. burgdorferi cell was studied by immuno-electronmicroscopy. Ultrathin sections of fixed and resin-embedded organisms were incubated with antibodies against p200 and p97 respectively. Bound antibodies were recognised by colloidal gold-labelled protein $A$. The gold particles were predominantly associated with the endoflagella in the periplasmic space (figs. 3,4). Antip200 and anti-p97 antibodies showed the same staining pattern along the entire flagella. The negative controls did not show a typical distribution.

To obtain further evidence for a flagellar localisation of the cloned antigen, flagella were isolated by the method of Coleman and Benach. ${ }^{9}$ Firstly the flagella were investigated by immuno-electronmicroscopy, by means of immune rabbit serum or with the isolated anti-p97 antibodies (fig. 5). The serum of the rabbit before immunisation served as a negative control. The antibodies, in contrast to the negative control, became bound along the entire flagellum. Secondly, after staining with Coomassie Blue, the Western blot of the purified flagella revealed two distinct bands, one intense, representing the major flagellar protein $\mathrm{p} 41$, and a second of less intensity, with $\mathrm{M}_{\mathrm{r}}$ of c. $97 \mathrm{Kda}$. The serum of the immunised rabbit, as well as the eluted human anti-p97 antibodies, stained the $97-\mathrm{Kda}$ protein only (fig. 6).

For its characterisation, the DNA of the recombi-
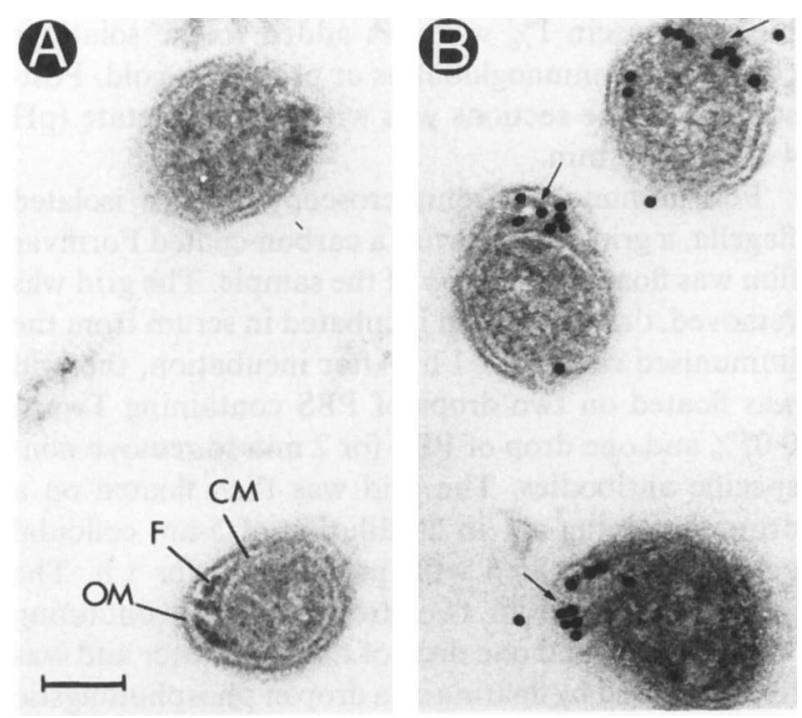

Fig. 3. Ultrathin sections of $B$. burgdorfericells with p200 antibodies and protein-A gold complexes. Bar $=100 \mathrm{~nm}$. (A) Negative control (F, flagella; CM, cytoplasmic membrane; OM, outer membrane). (B) Labelling with rabbit-IgG directed against p200. Arrows indicate immunogold particles in the periplasmic space associated with the flagellar bundle.

nant bacteriophages was isolated and cleaved with the endonuclease EcoRI. The resulting fragments were analysed by agarose gel electrophoresis. DNA fragments of the two $\lambda \mathrm{gt} 11$ arms of $19.6 \mathrm{~kb}$ and $24.1 \mathrm{~kb}$ and an additional DNA of about $6.6 \mathrm{~kb}$ in length could be recognised (fig. 7).
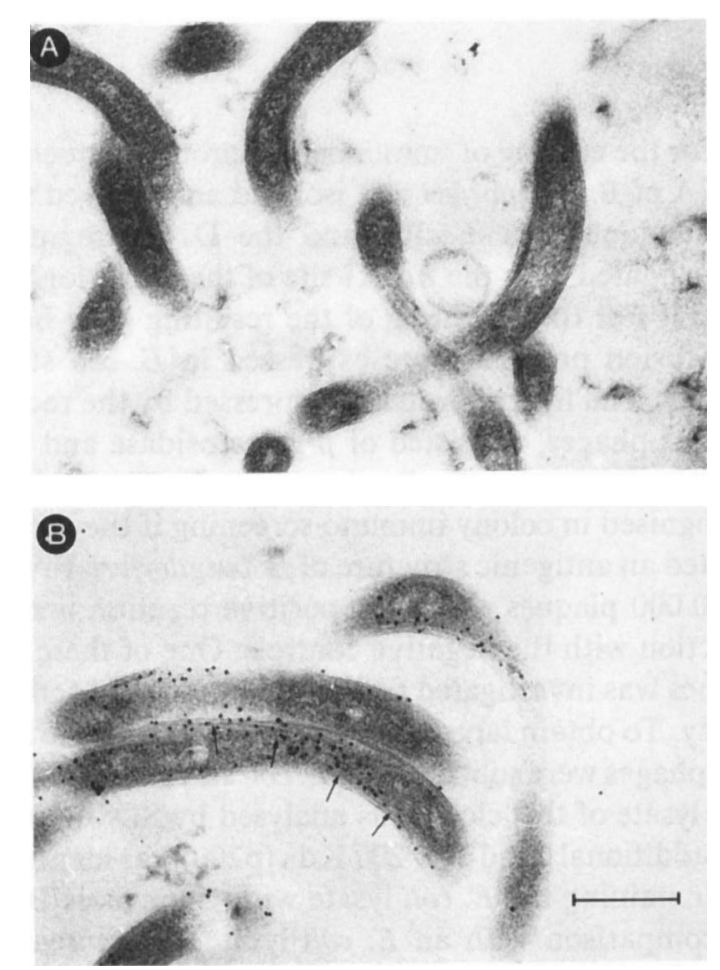

Fig. 4. Ultrathin sections of $B$. burgdorferi cells labelled with $\mathrm{p} 97$ antibodies and protein-A gold-complexes. Bar $=450 \mathrm{~nm}$. (A) Negative control with a $B$. burgdorferi antibody-negative human serum. (B) Labelling with p97 antibodies eluted from a blot membrane. Arrows indicate typical attachment sites of the gold marker, associated with the flagella. 

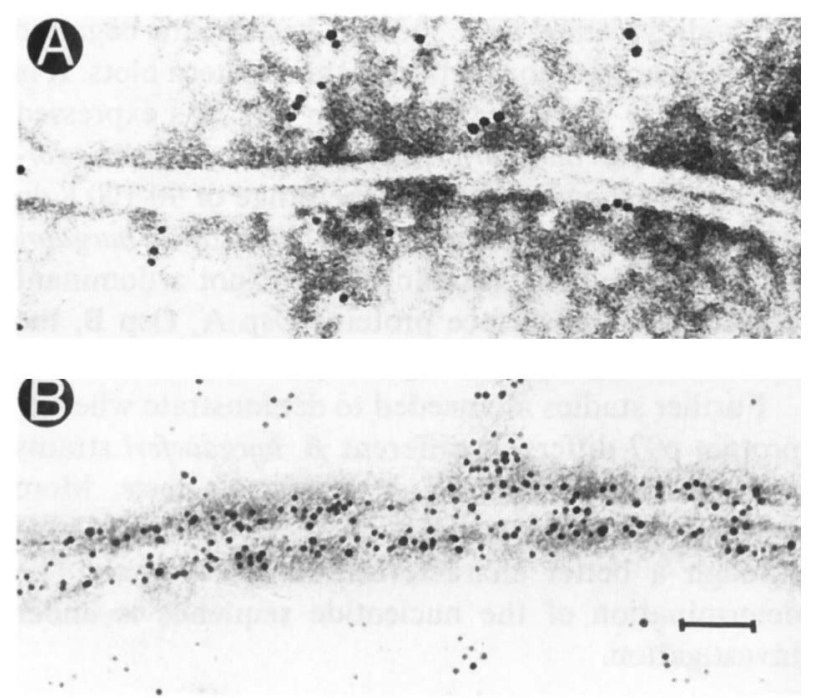

Fig. 5. Immuno-negative staining of protein p97 of the isolated flagella of $B$. burgdorferi. Bar $=30 \mathrm{~nm}$. (A) Negative control (negative rabbit serum); (B) with serum of immunised rabbit, the flagella are densely labelled with gold particles.

\section{Discussion}

The motility of the helical $B$. burgdorferi is brought about by $c .10$ flagella, located in the periplasmic space between the cytoplasmic membrane and the outer envelope ${ }^{27}$ Recently, the major flagellar protein $\mathrm{p} 41$ was characterised and the nucleotide sequence, coding for 336 amino acids, was determined. The sequence data demonstrated a high homology to the $33-\mathrm{Kda}$ flagellar protein of Treponema pallidum. ${ }^{9-11}$

Coleman and Benach isolated B. burgdorferi flagella by $\mathrm{CsCl}$ gradient centrifugation. ${ }^{9}$ In the SDS-PAGE of the product, stained with Coomassie Blue, protein

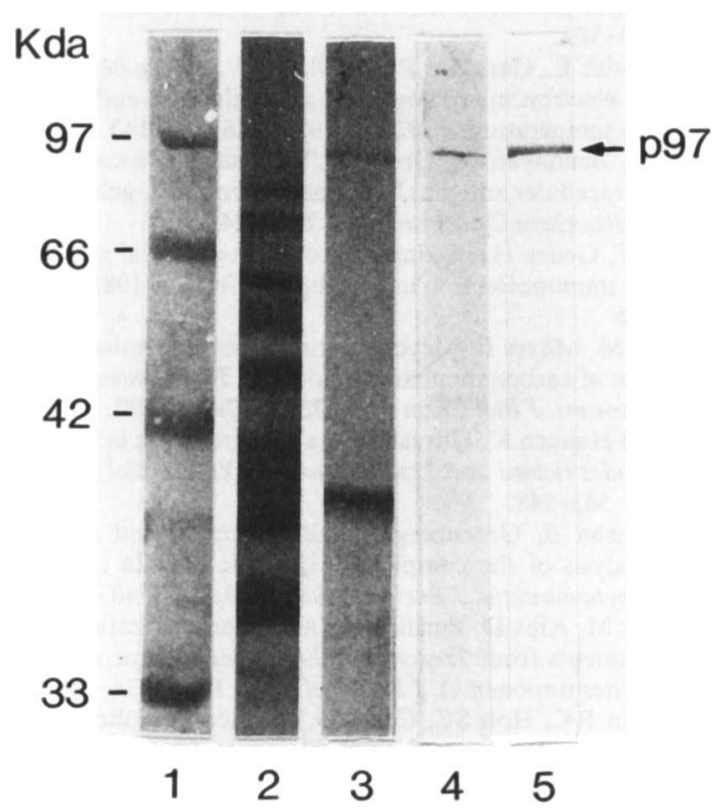

Fig. 6. Western blot of the purified flagella of B. burgdorferi: lane 1, mol. wt marker; 2, B. burgdorferi lysate, stained with Coomassie Blue; 3, isolated flagella, stained with Coomassie Blue; 4 , immunoreaction of the isolated flagella with human antibodies against $\mathrm{p} 97$; 5 , immunoreaction of the isolated flagella with serum of immunised rabbit.

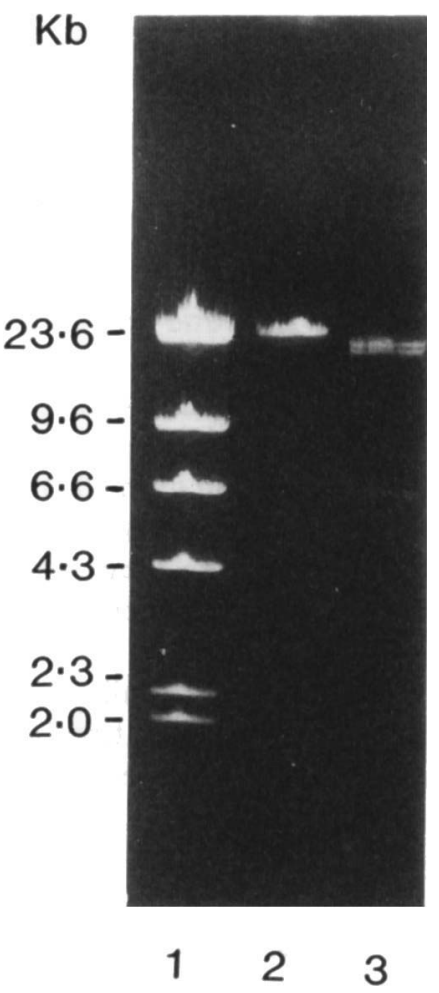

Fig. 7. Agarose gel electrophoresis of DNA of the recombinant $\lambda$ gtl1, stained with ethidium bromide: lane 1, marker DNA; 2 , undigested recombinant DNA; 3, recombinant DNA digested with EcoRI. The insert with a length of about $6600 \mathrm{Bp}$ is shown.

p41 and a minor band of $c .85 \mathrm{Kda}$ were identified. The authors suggested that this $85-\mathrm{Kda}$ protein might be a dimer of protein p41, but it is also possible that the protein was a different structural part of the flagella. It remained unclear whether the flagella in $B$. burgdorferi consisted of only $\mathrm{p} 4 \mathrm{l}$ subunits, or whether it was assembled from several structural proteins. Flagella of other spirochaetes, e.g., some treponemes or leptospires, consist of different proteins. ${ }^{28-31}$

In the present study, an antigenic hybrid protein was expressed in E. coli, by means of DNA fragments of $B$. burgdorferi ligated with the DNA of a $\lambda \mathrm{gt} 11$ bacteriophage. The resulting protein had an $M_{r}$ in the range of $200 \mathrm{Kda}$. The mass of $\beta$-galactosidase in the fusion protein was $114 \mathrm{Kda}$, so that the expressed borrelia polypeptide had an $\mathrm{M}_{\mathrm{r}}$ of $c .90 \mathrm{Kda}$. This was the minimum mass that the corresponding protein from $B$. burgdorferi could have. The native protein was identified by several methods as having an $\mathbf{M}_{\mathrm{r}}$ of $97 \mathrm{Kda}(\mathrm{p} 97)$. Antibodies directed against the hybrid protein p200 or the corresponding protein p97 of $B$. burgdorferi, characterised and identified in this report, reacted with antigens located in the region of the periplasmic flagella as shown by immuno-electronmicroscopy of the bacterial cells. The immunogold complexes were distributed along the total length of the flagella (as shown by longitudinal sections of borrelia cells marked with immunogold complexes and "on grid" immunolabelling of the isolated flagella) and at the position of the flagellar bundle in the periplasmic space (as shown by transverse sections). The results obtained from immuno-electronmicro- 
scopy of purified flagella also indicated that protein p97 was associated with the flagella. This evidence was impressively supported by the Western blot of the flagellar fraction.

The experimental data of the blots further suggested an absence of antigen structures common to protein p97 and the major flagellar protein p41. The latter was not a constituent of $\mathrm{p} 97$, and $\mathrm{p} 97 \mathrm{might}$, therefore, have been a structural entity of the whole flagella, but to a lesser extent than $\mathrm{p} 41$, as indicated by results of SDS-PAGE. It might be speculated that protein $\mathrm{p} 97$ is necessary for preservation of the flagellar structure. Similar proposals were made for the two flagellar proteins found in Treponema phagedenis ${ }^{31}$ and other types of spirochaetal flagella which consist of different proteins. $^{28}$

In sera of patients with clinically and serologically diagnosed Lyme disease, p97 antibodies, unlike p41 antibodies, could not always be detected. The p97

\section{References}

1. Steer AC. Lyme disease. $N$ Engl J Med 1989; 321 : 586-596.

2. Burgdorfer W. Discovery of the Lyme disease spirochete and its relation to tick vectors. Yale J Biol Med 1984; 57 : 515520.

3. Barbour AG, Hayes SF. Biology of Borrelia species. Microbiol Rev $1986 ; 50: 381-400$.

4. Howe TR, Mayer LW, Barbour AG. A single recombinant plasmid expressing two major outer surface proteins of the Lyme disease spirochete. Science $1985 ; 227$; 645-646.

5. Luft BJ, Jiang W, Munoz P, Dattwyler RJ, Gorevic PD. Biochemical and immunological characterization of the surface proteins of Borrelia burgdorferi. Infect Immun 1989; 57: 3637-3645.

6. Barbour AG, Garon CF. The genes encoding major surface proteins of Borrelia burgdorferi are located on a plasmid. Ann N Y Acad Sci 1988; 539: 144-153.

7. Bergström S, Bundoc VG, Barbour AG. Molecular analysis of linear plasmid-encoded major surface proteins, OspA and OspB, of the Lyme disease spirochete Borrelia burgdorferi. Mol Microbiol 1989; 3: 479-486.

8. Wilske B, Preac-Mursic V, Schierz G, Kühbeck R, Barbour AG, Kramer M. Antigenic variability of Borrelia burgdorferi. Ann N Y Acad Sci 1988; 539: 126-143.

9. Coleman JL, Benach JL. Identification and characterization of an endoflagellar antigen of Borrelia burgdorferi. $J$ Clin Invest $1989 ; 84$ : 322-330.

10. Gassmann GS, Kramer M, Göbel UB, Wallich R. Nucleotide sequence of a gene encoding the Borrelia burgdorferi flagellin. Nucleic Acids Res 1989; 17 : 3590.

11. Wallich R, Moter SE, Simon MM, Ebnet K, Heiberger A, Kramer MD. The Borrelia burgdorferi flagellum-associated 41-kilodalton antigen (flagellin). Molecular cloning, expression, and amplification of the gene. Infect Immun 1990; 58 : 1711-1719.

12. Hansen $\mathrm{K}$, Bangsborg JM, Fjordvang $\mathbf{H}$, Pedersen NS, Hindersson P. Immunochemical characterization of and isolation of the gene for a Borrelia burgdorferi immunodominant 60-kilodalton antigen common to a wide range of bacteria. Infect Immun 1988; 56: 2047-2053.

13. Preac-Mursic V, Wilske B, Schierz G. European Borrelia burgdorferi isolated from humans and ticks. Culture conditions and antibiotic susceptibility. Zentralbl Bakteriol Mikrobiol Hyg A 1986; 263: 112-118.

14. Barbour AG. Isolation and cultivation of Lyme disease spirochetes. Yale J Biol Med 1984; 57: 521-525.

15. Wassmann K, Borg-v. Zepelin M, Zimmermann O, Stadler M, Eiffert H, Thomssen R. Determination of immunoglobulin M antibody against Borrelia burgdorferi to differentiate between acute and past infections. In: Lyme borreliosis II Zentralbl Bakteriol Microbiol Hyg 1989; Suppl 18: 281-289.

16. Nakamura K, Pirtle RM, Inouye M. Homology of the gene antibodies seemed to be specific, because the negative controls showed no reaction in the Western blots. It is still unclear whether this protein $\mathrm{p} 97$ was expressed by different $B$. burgdorferi strains. Various $B$. burgdorferi strains show proteins in the range of $90-100 \mathrm{Kda}$ with different concentrations. ${ }^{8,9,32}$ In the $B$. burgdorferi strain we used, protein $\mathrm{p} 97$ was not a dominant protein like the surface proteins Osp A, Osp B, the common antigen or the flagellar protein $\mathrm{p} 41$.

Further studies are needed to demonstrate whether protein $\mathrm{p} 97$ differs in different $B$. burgdorferi strains and whether it is useful in diagnostic tests. More information about p97 would become available through a better characterisation of its gene. The determination of the nucleotide sequence is under investigation.

We thank Mrs Cyrilla Maelicke BSc for her help in preparing the manuscript.

coding for outer membrane lipoprotein within various Gram-negative bacteria. J Bacteriol 1979; 137: 595-604.

17. Sambrook J, Fritsch EF, Maniatis T. Molecular cloning: a laboratory manual, 2nd edn. Cold Spring Harbor, NY, Cold Spring Harbor Laboratory Press. 1989.

18. Huynh TV, Young RA, Davis RW. Constructing and screening in lambda gt10 and lambda gt11. In: Clover DM (ed) DNA-cloning, a practical approach. Washington, IRL Press. 1985.

19. Laemmli UK. Cleavage of structural proteins during the assembly of the head of bacteriophage T4. Nature 1970; 227: 680-685.

20. Gültekin H, Heermann KH. The use of polyvinylidenedifluoride membranes as a general blotting matrix. Anal Biochem $1988 ; 172: 320-329$.

21. Olmsted JB. Affinity purification of antibodies from diazotized paper blots of heterogenous protein samples. $J$ Biol Chem 1981 ; 256 : 11955-11957.

22. Jacobs E, Clad A. Electroelution of fixed and stained membrane proteins from preparative sodium dodecyl sulfate-polyacrylamide gels into a membrane trap. Anal Biochem 1986; 154 : 583-589.

23. Carlemalm E, Garavito RN, Villiger W. Resin development for electron microscopy and an analysis of embedding at low temperature. J Microsc 1982; 126: 123-143.

24. Roth J, Bendayan M, Orci L. Ultrastructural localization of intracellular antigens by the use of protein A-gold complex. $J$ Histochem Cytochem 1978; 26: 1074-1081.

25. Slot JW, Geuze HJ. Sizing of protein A-colloidal gold probes for immunoelectron microscopy. J Cell Biol 1981; 90: 533536.

26. Rohde M, Mayer F, Meyer O. Immunocytochemical localization of carbon monoxide oxidase in Pseudomonas carboxydovorans. J Biol Chem 1984; 259 : 14788-14792.

27. Hovind-Hougen $\mathbf{K}$. Ultrastructure of spirochetes isolated from Ixodes ricinus and Ixodes dammini. Yale J Biol Med 1984; 57: $543-548$.

28. Brahamsha B, Greenberg EP. Biochemical and cytological analysis of the complex periplasmic flagella from Spirochaeta aurantia. J Bacteriol $1988 ; 170$ : 4023-4032.

29. Bharier M, Allis D. Purification and characterization of axial filaments from Treponema phagedenis biotype reiterii (the Reiter treponeme). J Bacteriol 1974; 120 : 1434-1442.

30. Nauman RK, Holt SC, Cox CD. Purification, ultrastructure, and composition of axial filaments from Leptospira. $J$ Bacteriol 1969; 98 : 264-280.

31. Limberger RJ, Charon NW. Treponema phagedenis has at least two proteins residing together on its periplasmic flagella. $J$ Bacteriol 1986; 166: 105-112.

32. Wilske B, Preac-Mursic V, Schierz G, Busch KV. Immunochemical and immunological analysis of European Borrelia burgdorferi strains. Zentralbl Bakteriol Mikrobiol Hyg A $1986 ; 263: 92-102$ 